\title{
Article
}

\section{Venous leg ulcer management}

\author{
Nuttall, Dilyse
}

Available at http://clok.uclan.ac.uk/21251/

Nuttall, Dilyse ORCID: 0000-0002-0561-5229 (2017) Venous leg ulcer management. Nurse Prescribing, 15 (2). p. 62. ISSN 2052-2924

It is advisable to refer to the publisher's version if you intend to cite from the work.

10.12968/npre.2017.15.2.62

For more information about UCLan's research in this area go to

http://www.uclan.ac.uk/researchgroups/ and search for < name of research Group>.

For information about Research generally at UCLan please go to http://www.uclan.ac.uk/research/

All outputs in CLoK are protected by Intellectual Property Rights law, including Copyright law. Copyright, IPR and Moral Rights for the works on this site are retained by the individual authors and/or other copyright owners. Terms and conditions for use of this material are defined in the policies page.

\section{CLoK}

Central Lancashire online Knowledge www.clok.uclan.ac.uk

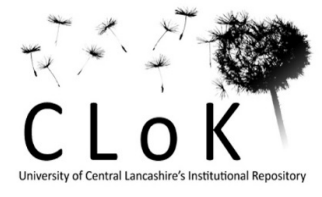




\section{Calculation Skills: Venous Leg Ulcer Management}

NICE (2016) define a leg ulcer as a loss of skin on the foot or the leg (below the knee), which has not healed within two weeks and are considered chronic if not healed within 4 weeks. The cause of venous leg ulcers is prolonged venous hypertension consequential of an insufficient calf muscle pump and/or chronic venous insufficiency (NICE, 2016). Symptoms of venous leg ulceration include swelling, pain and itching, sometimes accompanied by foul-smelling discharge and hardening of the skin around the skin-loss (NHS, 2016).

\section{Question 1}

It is estimated that between $0.1 \%$ and $0.3 \%$ of the UK population have a leg ulcer at any given time NICE, 2016).

(i) Based on a UK population size of 64.1 million, what is the minimum number of people with a venous leg ulcer?

(ii) What is the maximum number of people with a venous leg ulcer?

\section{Question 2}

SIGN (2010) identified that a study of 600 patients with leg ulcers found that $76 \%$ were venous.

(i) How many of the 600 patients had leg ulcers which were NOT venous?

\section{Question 3}

The key objective to managing leg ulcers is to achieve healing. However, according to NICE (2016), between $26 \%$ and $69 \%$ recur within 12 months. Local community nursing team A have 5 patients on their caseload whose chronic venous leg ulcers have been successfully treated and healed within the last month.

(i) What is the average recurrence rate?

(ii) Based on the average recurrence rate, how many of Team A's 5 patients are likely to experience a recurrence in their leg ulcer within the next year? Round your answer up or down to the nearest whole number.

\section{Question 4}

Stephanie, a 53 year old hairdresser has been diagnosed with a venous leg ulcer. Compression therapy was initiated but the ulcer has become infected. In accordance with JFC (2016), Stephanie is prescribed $500 \mathrm{mg}$ capsules of flucloxacillin, one to be taken four times daily, for seven days.

(i) How many 500mg capsules will need to be prescribed for Stephanie's course of treatment? 
(ii) The cost of flucloxacillin is $f 10.50$ for 28 capsules. What is the cost of each dose (assuming $500 \mathrm{mg}$ capsules are used)?

\section{Question 5}

Once Stephanie's infection is successfully treated, the compression therapy is resumed but it is determined that, in accordance with SIGN (2010) guidelines, pentoxifylline should be prescribed as an unlicensed indication, in combination with the compression therapy. The dose of pentoxifylline is $400 \mathrm{mg} 3$ times daily. Pentoxifylline is available as $400 \mathrm{mg}$ tablets at a cost of $£ 19.39$ for 90 tablets. It can be prescribed for up to 6 months.

(i) How many tablets will need to be prescribed for Stephanie for the period of $3^{\text {rd }}$ March to $5^{\text {th }}$ May inclusive?

(ii) What will the daily cost of this treatment be? (Round the cost of the daily dose up or down to the nearest pence).

(iii) If Stephanie requires treatment for 6 months (calculating one month as 30 days), how many tablets will Stephanie take in total.

\section{$\underline{\text { Answers }}$}

\section{Question 1}

It is estimated that between $0.1 \%$ and $0.3 \%$ of the UK population have a leg ulcer at any given time NICE, 2016).

(i) $100 \%=64100000$

$0.1 \%=64100000 \div 1000=64100$

Minimum number of people with a venous leg ulcer is 64100

(ii) $0.3 \%=64100 \times 3=192300$

Maximum number of people with a venous leg ulcer is 192300

\section{Question 2}

(i) $100 \%=600$

$1 \%=600 \div 100=6$

$24 \%=24 \times 6=144$

\section{Question 3}


(i) Recurrence rate $=26-69 \%$

Average $=(26+69) \div 2=47.5 \%$

(ii) $100 \%=5$

$1 \%=5 \div 100=0.05$

$47.5 \times 0.05=2.375$

Rounded down $=2$

\section{Question 4}

(i) Daily dose $=4 \times 1$ capsule $=4$ capsules

Total course $=4 \times 7=28$ capsules

(ii) 28 capsules $=£ 10.50$

1 capsule $=1050 \div 28=37.5 p$

\section{Question 5}

Once Stephanie's infection is successfully treated, the compression therapy is resumed but it is determined that, in accordance with SIGN (2010) guidelines, pentoxifylline should be prescribed as an unlicensed indication, in combination with the compression therapy. The dose of pentoxifylline is $400 \mathrm{mg} 3$ times daily. Pentoxifylline is available as $400 \mathrm{mg}$ tablets at a cost of $£ 19.39$ for 90 tablets. It can be prescribed for up to 6 months.

(i) Number of days $3^{\text {rd }}$ March to $5^{\text {th }}$ May inclusive $=64$

Tablets daily $=3$

Tablets needed $=64 \times 3=192$

(ii) 90 tablets $=f 19.39$

Daily $=(£ 19.39 \div 90) \times 3=64.63333 p(65 p$ rounded up $)$

(iii) 6 months $=30 \times 6=180$ days

3 tablets $\times 180$ days $=540$ tablets

\section{$\underline{\text { References }}$}

Joint Formulary Committee (2016) British National Formulary 72. London: BMA \& RPSGB

NHS Choices (2016) Venous leg ulcer. Online available at: http://www.nhs.uk/Conditions/Leg-ulcervenous/Pages/Introduction.aspx

NICE (2016) Clinical knowledge summaries: Leg ulcers - venous. Online available at:

https://cks.nice.org.uk/leg-ulcer-venous 
SIGN (2010) Management of chronic venous leg ulcers: A national guideline 120. Edinburgh: SIGN 